Acta Zoológica Mexicana (nueva serie), Volume 38, 1-12.

https://doi.org/10.21829/azm.2022.3812318

Original paper

\title{
Intra-population variation of body temperature of the lizard Sceloporus anahuacus (Squamata: Phrynosomatidae) in Sierra del Ajusco, Mexico
}

\section{Variación intrapoblacional de la temperatura corporal de la lagartija Sceloporus anahuacus (Squamata: Phrynosomatidae) en la Sierra del Ajusco, México}

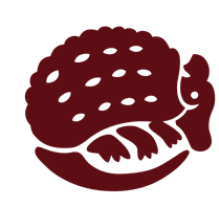

OPEN ACCESS
*Corresponding author:

iD Uri Omar García-Vázquez urigarcia@gmail.com

Cite:

Güizado-Rodríguez, M. A., GarcíaVázquez, U. O., Solano-Zavaleta, I., Maceda-Cruz, R. J., Duifhuis-Rivera, C. (2022) Intra-population variation of body temperature of the lizard Sceloporus anahuacus (Squamata: Phrynosomatidae) in Sierra del Ajusco, Mexico. Acta Zoológica Mexicana (nueva serie), 38, 1-12. 10.21829/azm.2022.3812318 elocation-id: e3812318

Received: 23 August 2020 Accepted: 04 January 2022 Published: 22 January 2022

\section{1'MARTHA ANAHí GÜIZADO-RODRÍGUEZ, (iD 2*URI OMAR GARCíA- VÁZQUEZ, ${ }^{3}$ ISRAEL SOLANO-ZAVALETA, ${ }^{2}$ ROLANDO JONATHAN MACEDA-CRUZ, ${ }^{2}$ CHRISTOPHER DUIFHUIS-RIVERA}

\begin{abstract}
${ }^{1}$ Laboratorio de Zoología, División de Biología, Instituto Tecnológico Superior de Zacapoaxtla, Tecnológico Nacional de México, Carretera AcuacoZacapoaxtla Km. 8, Col. Totoltepec, Zacapoaxtla, Puebla, C. P. 73680, México. ${ }^{2}$ Laboratorio de Sistemática Molecular, Carrera de Biología, UMIEZ, Facultad de Estudios Superiores Zaragoza, Universidad Nacional Autónoma de México, Batalla 5 de mayo s/n, Col. Ejército de Oriente, Ciudad de México, Iztapalapa, C. P. 09230, México.

${ }^{3}$ Departamento de Ecología y Recursos Naturales, Facultad de Ciencias, Universidad Nacional Autónoma de México, Ciudad Universitaria, C. P. 04510 Ciudad de México, México.
\end{abstract}

Responsible editor: Eduardo Pineda

\begin{abstract}
We evaluated intra-population variation of body temperature of the Mexican lizard Sceloporus anahuacus (Phrynosomatidae) in Sierra del Ajusco, Mexico. The geographic distribution of this lizard is restricted to the higher parts of the mountains bordering the south of the Mexican Valley in Mexico City. The study of the body temperature of $S$. anahuacus and its relationship with the environment is important because high elevation taxa are seriously threatened by climate change. For that reason, and compared body temperature between sex, age class, reproductive condition and activity state. Overall, mean body temperature was $26.2 \pm 5.5^{\circ} \mathrm{C}$ with a range between 9-39 ${ }^{\circ} \mathrm{C}$. We did not find differences between body temperatures of males and females. However, we found significant differences
\end{abstract}


depending on activity state in both sexes. In females, body temperature did not vary as a function of age class or reproductive status. Instead, we found differences in body temperature between males of different age classes. Juveniles had the highest body temperature, probably due to differential temperature requirements associated with development. On the other hand, body temperature of active and inactive $S$. anahuacus was strongly associated with environmental temperature, perhaps due to sedentary habits and territorial behavior. Exploring why such variation exists on body temperature regulation may provide information on factors influencing the survivorship of this endemic Mexican lizard.

Key words: thermal ecology; ectotherms; reptiles; pine forest; Sceloporus anahuacus; Mexico

RESUMEN. Evaluamos la variación intrapoblacional de la temperatura corporal de la lagartija mexicana Sceloporus anahuacus (Phrynosomatidae) en la Sierra del Ajusco, México. La distribución geográfica de esta lagartija se limita a las partes más altas de las montañas que bordean el sur del valle mexicano en la Ciudad de México. El estudio de la temperatura corporal de S. anahuacus y su relación con el medio ambiente es importante debido a que los taxones de alta elevación están seriamente amenazados por el cambio climático. Por esa razón, exploramos la relación de la temperatura corporal de $S$. anahuacus con la temperatura del aire y del sustrato, y comparamos la temperatura corporal entre sexos, clase de edad, condición reproductiva y el estado de actividad. En general, la temperatura corporal promedio fue de $26.2 \pm 5.5^{\circ} \mathrm{C}$ con un rango entre $9-39{ }^{\circ} \mathrm{C}$. No encontramos diferencias entre las temperaturas corporales de machos y hembras. Sin embargo, encontramos diferencias significativas según el estado de actividad de ambos sexos. En las hembras, la temperatura corporal no varió en función de la edad o el estado reproductivo. En cambio, encontramos diferencias en la temperatura corporal entre machos de diferentes clases de edad. Los juveniles tuvieron la temperatura corporal más alta, probablemente debido a los requisitos de temperatura diferencial asociados con el desarrollo. Por otro lado, la temperatura corporal de S. anahuacus activos e inactivos estuvo fuertemente asociada con la temperatura ambiental, tal vez debido a hábitos sedentarios y comportamiento territorial. Explorar por qué existe esta variación en la regulación de la temperatura corporal puede proporcionar información sobre los factores que influyen en la supervivencia de esta lagartija endémica mexicana.

Palabras clave: ecología térmica; ectotermos; reptiles; bosque de pino; Sceloporus anahuacus; México

\section{INTRODUCTION}

In squamate reptiles, body temperature exerts a significant influence on a variety of physiological and behavioral mechanisms, which have effects on survivorship, growth rate and reproductive success (Sinervo \& Adolph, 1989). For example, body temperature affects locomotion (Chen et al., 2003), immune infection (Mondal \& Rai, 2001), sensory input (Stevenson et al., 1985), foraging ability (Pianka, 1973; Ayers \& Shine, 1997), predation risk (Herczeg et al., 2008), food assimilation and growth (Angilletta, 2001; Chen et al., 2003; Tattersall et al., 2004; Brown \& Griffin, 2005), courtship (Stapley, 2006), offspring fitness (Mathies \& Andrews, 1997), sex determination (Janzen, 1994; Juliana et al., 2004), activity period (Llewelyn et al., 2005; López-Alcaide et al., 2014) and 
microhabitat selection (Pianka, 1973; Angert et al., 2002; Amat et al., 2003; Lara-Reséndiz et al., 2014).

Importantly, reptile body temperature is constrained by phylogeny (Casas-Andreu \& Gurrola-Hidalgo, 1993; Andrews, 1998), environment (Gillis, 1991; Angilletta, 2001) and life history characteristics like sex (Lee, 1980), reproductive status (Mathies \& Andrews, 1997) and age class (Lemos-Espinal et al., 1998). Therefore, reptiles mainly use behavioral mechanisms to regulate body temperature for optimal function of cellular and organismal processes (Bartholomew, 1982). Behavioral thermoregulation includes changes in posture (Kearney, 2001), activity periods (Grant \& Dunham, 1988) and microhabitat selection (Adolph, 1990). Consequently, they tend to explore the temporal and spatial variability of the thermal environment, which promotes a close relationship between the organism's body temperature and the environment (Mathies \& Andrews, 1995).

Genus Sceloporus is composed by 111 species (Uetz et al., 2022) and has a wide latitudinal and altitudinal distribution from western Panama in Central America to Washington in the United States (Andrews, 1998). Field body temperatures measured during normal activity periods range from $14.2-40{ }^{\circ} \mathrm{C}$ with an average of $33.9^{\circ} \mathrm{C}$ (Bogert, 1949; Sinervo, 1990; Smith \& Ballinger, 1994; Clusella-Trullas \& Chown, 2014). Species for which body temperatures have been measured on thermal gradients in the laboratory exhibit preferred temperatures from $28.6-38.8{ }^{\circ} \mathrm{C}$, with an average of $33.96{ }^{\circ} \mathrm{C}$ (Brattstrom, 1965; McGinnis, 1966; Sinervo \& Adolph, 1989; Mathies \& Andrews, 1997; Andrews et al., 1999). For that reason, genus Sceloporus has long been considered to be thermally conservative (Andrews, 1998). However, there is not a consistent pattern between field body temperature and preferred temperature in Sceloporus species with respect to latitude and altitude (Clusella-Trullas \& Chown, 2014).

Sceloporus anahuacus Lara-Góngora, 1983, is a small viviparous phrynosomatid lizard inhabiting open pine forest. They are indicators of forest disturbance since they proliferate in areas of intense commercial clearing, recovering burns, or any other kind of disturbance that creates a more open forest structure (Lara-Góngora, 1983). Until now, the ecology of S. anahuacus is relatively unstudied, although there are some contributions concerning thermal ecology (ÁvilaBocanegra et al., 2012), selected body temperature under laboratory conditions (Lara-Reséndiz \& García-Vázquez, 2013) and thermal habitat quality (Lara-Reséndiz et al., 2014). However, what is usually overlooked in these efforts is that species can be composed of different populations or geographical groups across their ranges, which are under different selective pressures deriving in an independently potential response to climate (Araújo et al., 2006; Güizado-Rodríguez et al., 2012). Therefore, the more information we can gather on the temperature relationships of lizards across all its distribution ranges, the better we might be able to predict the thermoregulatory profiles and propose appropriate conservation strategies. For that reason, in this paper, we analyzed the relationship with air and substrate temperatures, and compared body temperature between sex, age class, reproductive condition and activity state. 


\section{MATERIALS AND METHODS}

Study site. This study was carried out in the Ejido Magdalena Petlatalco, Delegación Magdalena Contreras, Sierra del Ajusco, Ciudad de México, México, (19 13' 15.5" N, 99 17' 8.2" W) from 3,500 to 3,930 meters above sea level. The climate of the study area is temperate semihumid with a mean annual temperature of $7.5-13.5^{\circ} \mathrm{C}$ and mean annual rainfall of $1,340 \mathrm{~mm}$ with less than $5 \%$ of this occurring in the winter (García, 1973). Vegetation includes pine forest (Pinus hartwegii) and grasslands (Álvarez del Castillo, 1987).

Field work. We collected 539 lizards (active and inactive lizards) during the period from 1,000 to $1,600 \mathrm{~h}$, from August 2007 through April 2009. This work was part of a project including demographic and ecological aspects of $S$. anahuacus. Each lizard was permanently marked by clipping toes, and only one observation per individual was used in statistical analyses. If more than one observation was available for an individual, a single observation was chosen at random for inclusion in statistical analyses.

Activity state was determined as follows: active lizards were basking on rocks or fallen trees, foraging, pursuing mates, whereas inactive lizards were beneath rocks or hidden under vegetation and debris in crevices or depressions (Güizado-Rodríguez et al., 2011). Active lizards were captured by noosing and returned to their habitat after collecting data. We measured body temperature from lizards' cloaca $(T b)$ and obtained substrate (Ts on the site where the lizard was first observed) and air ( $T a 5 \mathrm{~cm}$ off the ground) temperatures with a quick-reading thermometer (model 4D2672, Miller and Weber, Inc., New York; $0-50 \pm 0.2^{\circ} \mathrm{C}$ ). Care was taken to prevent the temperature from being influenced by handling, therefore all data from lizards requiring extensive capture effort was excluded for temperature records. To avoid errors, we only analyzed data collected within $10 \mathrm{~s}$ after capture (Lee, 1980; Gillis, 1991). In addition to Tb, we recorded snout-vent length (SVL) with a digital caliper to $0.1 \mathrm{~mm}$ and body mass was measured with a Pesola scale (Pesola AG, Baar, Switzerland) to the nearest $0.2 \mathrm{~g}$. Sex was determined by examining the sexually dimorphic scales and color pattern (Lemos-Espinal et al., 1997a). Female reproductive state (pregnant vs. nonpregnant) was determined by palpation (Lemos-Espinal et al., 1997b).

Statistics. The assumptions of normality and homogeneity of variances were tested and met with Shapiro-Wilk and Bartlett tests, respectively. We performed an Analysis of Covariance by sex to evaluate the effect of factors such as age class (offspring, juvenile, adult), activity state (active and inactive) and in the case of females, the reproductive condition (reproductive and no reproductive) on lizard's T $b$ including $T a$, Ts and SLV of lizards as covariates. Hypotheses were tested with ANOVA (such as $\mathrm{F}$ tests). Data are presented as mean \pm standard deviation (SD). Statistical analyses were performed with XLSTAT (Addinsoft, 2014). Data analysis and statistical software for Microsoft Excel, Paris, France; http:// www.xlstat.com) software implementing an $\alpha$ of 0.05 to indicate significance.

\section{RESULTS}

Mean $\mathrm{T} b$ for active lizards was $28.31 \pm 3.6^{\circ} \mathrm{C}\left(17-39^{\circ} \mathrm{C}, \mathrm{n}=365\right)$. On the other hand, mean $\mathrm{T} b$ for inactive lizards was $22.01 \pm 6.4\left(9-33^{\circ} \mathrm{C}, \mathrm{n}=174\right)$. Mean SVL in males was $38.5 \pm 9.9 \mathrm{~mm}(\mathrm{n}=213)$ and in females was $37.6 \pm 7.8 \mathrm{~mm}(n=326)$. Mean body mass of males was $2.4 \pm 1.8 \mathrm{~g}(n=213)$ 
and for females was $2.0 \pm 1.1 \mathrm{~g}(\mathrm{n}=326)$. $\mathrm{T} b$ of individuals with different sex, age class and activity state are shown in Table 1. Mean Ta was $17.63 \pm 3.11{ }^{\circ} \mathrm{C}$ and mean Ts was $19.31 \pm 6.46{ }^{\circ} \mathrm{C}$. In females, according to the goodness of fit and ANOVA test performed in global factorial ANCOVA model, the set of independent variables (age, SVL, reproductive state, activity state, $\mathrm{T} a$ and Ts) analyzed significantly explain the variation in lizards' $T b(\mathrm{R} 2=0.52 ; F 7,283=43.857 ; P<0.0001)$. Furthermore, the Type I sum of squares indicates that the independent variables that provide the greatest amount of information on lizards' T $b$ were Ts $(F 1,289=201.131 ; P<0.0001), \mathrm{Ta}(F 1,289$ $=66.567 ; P<0.0001)$ and the activity state $(F 1,289=32.947 ; P<0.0001)$ whereas SVL $(F 1,289=$ $0.303 ; P=0.583)$, age class $(F 1,289=1.508 ; P=0.223)$ and reproductive state $(F 1,289=3.035 ; P$ $=0.223$ ) did not have an effect on $\mathrm{T} b$.

Table 1. Field body temperature of different sex, age class and activity state in Sceloporus anahuacus. Mean $( \pm S D)$. Abbreviations: $M=$ Male; $F=$ Female; $n=$ number; $M x=$ Maximum; $M n=$ Minimum; $O f f=O f f s p r i n g ;$ Juv = Juvenile; Adu = Adult; Act $=$ Active; Ina = Inactive.

\begin{tabular}{|c|c|c|c|c|c|c|c|c|c|c|c|c|c|c|}
\hline \multirow{2}{*}{ Sex } & \multicolumn{4}{|c|}{$\mathbf{T}_{b}$} & \multicolumn{5}{|c|}{ Age Class } & \multicolumn{5}{|c|}{ Activity State } \\
\hline & $\mathrm{x} \pm \mathrm{SD}$ & $n$ & $M x$ & $\mathrm{Mn}$ & & $\mathrm{SD}\left({ }^{\circ} \mathrm{C}\right)$ & $n$ & $M x$ & $\mathrm{Mn}$ & & $\mathrm{x} \pm \mathrm{SD}\left({ }^{\circ} \mathrm{C}\right)$ & $n$ & $M x$ & $\mathrm{Mn}$ \\
\hline \multirow{3}{*}{$\mathrm{M}$} & & & & & $\overline{\text { Off }}$ & $25.4 \pm 4.8$ & 49 & 32 & 15 & $\overline{\text { Act }}$ & $28.58 \pm 3.45$ & 149 & 36 & 18 \\
\hline & $26.7 \pm 5.4$ & 213 & 36 & 9 & Juv & $27.6 \pm 4.3$ & 55 & 34 & 14 & Ina & $22.46 \pm 6.67$ & 63 & 33 & 9 \\
\hline & & & & & Adu & $26.8 \pm 6.0$ & 110 & 36 & 9 & & & & & \\
\hline \multirow{3}{*}{$F$} & & & & & Off & $26.1 \pm 4.3$ & 52 & 32 & 16 & Act & $28.12 \pm 3.76$ & 216 & 39 & 17 \\
\hline & $25.9 \pm 5.6$ & 326 & 39 & 12 & Juv & $27.0 \pm 5.6$ & 87 & 39 & 12 & Ina & $21.76 \pm 6.27$ & 110 & 33 & 12 \\
\hline & & & & & Adu & $25.5 \pm 5.8$ & 186 & 34 & 12 & & & & & \\
\hline
\end{tabular}

In the case of males, the independent variables (age class, SVL, activity state Ta and Ts) analyzed also significantly explain the variation in lizards' $\mathrm{T} b(\mathrm{R} 2=0.57 ; F 6,193=43.218 ; P$ $<0.0001)$. The Type I sum of squares indicates that the independent variables that provide the greatest amount of information on lizards' T $b$ were Ts $(F 1,198=197.164 ; P<0.0001), \mathrm{T} a(F 1,198$ $=16.389 ; P<0.0001)$ and the activity state $(F 1,198=38.097 ; P<0.0001)$ whereas SVL $(F 1,198=$ $1.444 ; P=0.238)$ and age class $(F 1,198=4.769 ; P=0.301)$ did not have an effect on $\mathrm{T} b$.

On the one hand, the post hoc analysis (Tukey HSD) with a confidence interval of $95 \%$ did not detect any significant difference in females $T b$ between age classes and reproductive condition, but a difference was found between females with different activity state $(P<0.0001)$. In the other hand, with respect to males the post hoc analysis identified significant differences between individuals with different activity state $(P<0.0001)$ and age classes (juvenile vs. adult, $P=0.025)$.

\section{DISCUSSION}

Our study provides an examination of field body temperature variability of Sceloporus anahuacus at intraspecific level. Although found at a wide range of latitudes and altitudes and in a variety of habitats, all Sceloporus species studied maintain similar Tb during activity in nature and in thermal gradients in laboratory (Bogert, 1949; Wilhoft \& Anderson, 1960; Brattstrom, 1965; Mayhew, 1968; 
McGinnis, 1966; Mueller, 1970; Avery, 1982; Crowley, 1985). This study showed that active S. anahuacus had one of the lowest $\mathrm{Tb}\left(28.3^{\circ} \mathrm{C}\right)$ registered for members of genus Sceloporus (Vial, 1984; Andrews, 1998; Andrews et al., 1999). However, Ávila-Bocanegra et al. (2012) reported a significantly warmer $\mathrm{Tb}\left(30.88 \pm 0.14{ }^{\circ} \mathrm{C}\right)$ for another $\mathrm{S}$. anahuacus population. This may be due to the fact that population studied by these authors is located at a lower altitude site $(3,200 \mathrm{~m})$ with a higher ambient temperature $\left(\mathrm{T} a=20.88 \pm 0.24{ }^{\circ} \mathrm{C} ; \mathrm{T} s=20.47 \pm 0.24{ }^{\circ} \mathrm{C}\right)$ than the registered in our study $\left(\mathrm{T} a=17.63 \pm 3.11^{\circ} \mathrm{C} ; \mathrm{Ts}=19.31 \pm 6.46^{\circ} \mathrm{C}\right)$.

Such as $S$. anahuacus, there are other Sceloporus species that show a low $T b$ like $S$. malachiticus ( $\mathrm{T} b=28.6{ }^{\circ} \mathrm{C}$; Vial, 1984), S. mucronatus mucronatus $\left(\mathrm{T} b=29.4 \pm 0.7{ }^{\circ} \mathrm{C}\right.$; LemosEspinal et al., 1997a), S. bicanthalis ( $\mathrm{Tb}=28.8 \pm 0.69{ }^{\circ} \mathrm{C}$; Andrews et al., 1999) and S. palaciosi (Tb $=27.82 \pm 5.31{ }^{\circ} \mathrm{C}$; Güizado-Rodríguez et al., 2011). This low $\mathrm{Tb}$ is presumably due to thermal constraints imposed by the spatial and temporal distribution of environmental temperatures that determine daily and seasonal activity because usually at high elevations, thermal quality is low (Lymburner \& Blouin-Demers, 2020). Lara-Reséndiz et al., (2014) evaluated the thermal habitat quality of a lizard community along an altitude gradient, in order to determine if thermal environment has an effect on distribution and thermal ecology. Authors suggest that altitude and vegetation have an influence on thermal quality, therefore thermal ecology studies should be carried out at different spatial scales to understand the factors involved in thermal niche and thermoregulation. According to the results showed by the authors, the operative temperatures where S. anahuacus lives, had the lowest values compared to other studied sites. This means that landscape characteristics, have a influence on the thermal properties of the habitat and therefore thermoregulatory opportunities for S. anahuacus.

In thermally challenging habitats, ectotherms may passively reach body temperature in the field and not match preferred temperatures. In that situation, ectotherms should thermoregulate, frequently being exposed to predators, or otherwise maintain suboptimal temperatures, with the concomitant physiological costs (Zamora-Camacho et al., 2016). According to Lara-Reséndiz et al. (2014), S. anahuacus habitat has a low thermal quality, therefore, when lizards are under laboratory thermal gradients they select a higher body temperature $\left(32.64 \pm 2.73^{\circ} \mathrm{C}\right.$, range $\left.=26.0-36.5^{\circ} \mathrm{C}\right)$ (Lara-Reséndiz \& García-Vázquez, 2013) than in the field $\left(\mathrm{T} b=28.31 \pm 3.6^{\circ} \mathrm{C}\right)$.

Another thermal constrain for $S$. anahuacus could be the availability of suitable microhabitats for thermoregulation due to deforestation, since this activity promotes openness patches and reduce habitat heterogeneity and sites available for thermoregulation. Sierra del Ajusco is located within the Transverse Volcanic Belt, which has a long history of human disturbance that has increased in recent decades due to its boundary with one of the world's largest cities, the metropolitan area of Mexico City. These disturbances are the result of increasing population density, land use change, forest and wildlife resources exploitation, and the effects of contamination (Granados Sánchez et al., 2004). However, as a descriptive study, there were not enough data to elucidate the ultimate and proximate causes of the low $\mathrm{T} b$ found in S. anahuacus. To further clarify this, we need to address the influence of the spatial distribution of operative temperatures on activity and microhabitat use using biophysical models that can provide 
information to some extent about how this species thermoregulates and will lend insight into the observed patterns for these lizards (Heath, 1964).

On the other side, body temperature of S. anahuacus did not differ between sexes; this can be due to similar use of microhabitats, activity periods and feeding habits by males and females such as in other diurnal lizards (Güizado-Rodríguez et al., 2011). Unlike some sympatric species like S. mucronatus, shows a difference in $\mathrm{T} b$ between males and females due to different activity periods (e.g., females emerge later than males) or because females may be forced to use suboptimal basking sites by males (Lemos-Espinal et al., 1997a).

In addition, we did not find evidence for variation in $T b$ as a function of reproductive condition in females. This may be the result of females being unable to alter their $\mathrm{T} b$ due to phylogenetic constraints (Lemos-Espinal et al., 1997b), or because differences between early pregnancy-stage and non-pregnant females may be difficult to detect. Another reason could be that $S$. anahuacus females have not had the opportunity to choose microhabitats with better thermal conditions; therefore, it is probable that pregnant females do not reach unfavorable body temperatures for embryos. Females of some Sceloporus species exhibit lower Tb when gravid or pregnant because normal activity temperatures are detrimental to embryos (Van Damme et al., 1986; Andrews \& Rose, 1994). However, Ávila-Bocanegra et al. (2012) found that S. anahuacus pregnant females had a higher $\mathrm{T} b$ than non-pregnant females. This is due to the altitude of the studied site where S. anahuacus was observed by Ávila-Bocanega et al. (2012). Isidro Fabela at the northeastern Estado de México has a lower altitude than the Ajusco where S. anahuacus was collected during this study. According to work carried out by Lara-Reséndiz et al. (2014), El Ajusco, Ciudad de México is a site with low thermal quality and a highly variable operating temperature (To) $\left(-8.5-68.4^{\circ} \mathrm{C}\right)$, therefore, S. anahuacus tends to show a narrow selected body temperature (Tsel) with intervals $\left(\leq 2.1^{\circ} \mathrm{C}\right)$, which means that cost of thermoregulation is high for this species mainly because conifer forests have greater coverage and the availability of perching sites such as rocks, trees or sunny patches on the ground for this high mountain phrynosomatid are scarce.

We also did not find a difference between $T b$ among different female age classes. This may be because the environment lacks a wide range of temperatures, and all age classes are constrained to select similar thermal microclimates. However, there are no data about age class specific behavior in S. anahuacus; therefore, we need to concentrate our efforts to answer these kinds of questions in future studies. In the case of males, we found differences between $T b$ among different age classes. Juveniles had the highest $T b$ and the offsprings presented the lowest $T b$. In some diurnal reptiles, juveniles select higher body temperatures than adults (Pérez-Quintero, 1994), presumably due to differential temperature requirements associated with development (Hitchcock \& McBrayer, 2006).

Sceloporus lizards are sit-and-wait insectivores that spend much of their time perched conspicuously on rocks and fallen trees. For this reason, they maintain a strong relationship with the microhabitat temperature. We found a significant relationship between $\mathrm{T} b$ and $T a$ and $T s$ in both sexes of $S$. anahuacus. This strong relationship may be due to sedentary habits and territorial behavior of Sceloporus (Pianka \& Vitt, 2003). Although, Ávila-Bocanegra et al. (2012) found slight 
variation in body temperature explained by environmental temperatures, which suggest that these lizards may be able to regulate their body temperatures to some extent.

ACKNOWLEDGMenTS. We thank R. Carrasco-García for her support in the field work and to T. Devitt for his comments. Financial support was provided by Universidad Nacional Autónoma de México grant SDEI-PTID-02 (Manejo de Ecosistemas y Desarrollo Humano). Lizards were collected under a scientific collecting and animal care permit FAUT 0243 to U. O. García-Vázquez issued by the Secretaría del Medio Ambiente y Recursos Naturales.

\section{LITERATURE CITED}

Adolph, S. C. (1990) Influence of behavioral thermoregulation on microhabitat use by two Sceloporus lizards. Ecology, 71, 315-327. https://doi.org/10.2307/1940271

Álvarez del Castillo, C. (1987) La vegetación de la Sierra del Ajusco. Cuaderno de Trabajo 33. Departamento de Prehistoria, INAH, México, Distrito Federal, México, 74 pp.

Amat, F., Llorente, G. A., Carretero, M. A. (2003) A preliminary study on thermal ecology, activity times and microhabitat use of Lacerta agilis (Squamata: Lacertidae) in the Pyrenees. Folia Zoologica, 52, 413-422.

Andrews, R. M. (1998) Geographic variation in field body temperature of Sceloporus lizards. Journal of Thermal Biology, 23, 329-334. https://dx.doi.org/10.1016/S0306-4565(98)00018-7

Andrews, R. M., Méndez-de la Cruz, F. R., Villagrán-Santa Cruz, M., Rodríguez-Romero, F. (1999) Field and selected body temperatures of the lizards Sceloporus aeneus and Sceloporus bicanthalis. Journal of Herpetology, 33, 93-100. https://dx.doi.org/10.2307/1565547

Andrews, R. M., Rose, B. R. (1994) Evolution of viviparity: constrains on egg retention. Physiological Zoology, 67, 1006-1024. https://dx.doi.org/10.1086/physzool.67.4.30163876

Angert, A. L., Hutchison, D., Glossip, D., Losos, J. B. (2002) Microhabitat use and thermal biology of the collared lizard (Crotaphytus collaris collaris) and the fence lizard (Sceloporus undulatus hyacinthinus) in Missouri Glades. Journal of Herpetology, 36, $23-29$. https://dx.doi.org/10.1670/0022-1511(2002)036[0023:MUATBO]2.0.CO;2

Angilletta, M. J. Jr. (2001) Thermal and physiological constraints on energy assimilation in a widespread lizard (Sceloporus undulatus). Ecology, 82, 3044-3056. https://dx.doi.org/10.2307/2679833

Araújo, M. B., Thuiller, W., Pearson, R. G. (2006) Climate warming and the decline of amphibians and reptiles in Europe. Journal of Biogeography, 33, 1712-1728. https://doi.org/10.1111/j.1365-2699.2006.01482.x

Avery, R. A. (1982) Field studies of body temperatures and thermoregulation. Pp. 93-166. In: C. Gans, F. H. Pough (Eds.). Biology of the Reptilia. Vol. 12. Academic Press, New York, USA. 
Ávila-Bocanegra, L. E., Smith, G. R., Woolrich-Piña, G. A., Lemos-Espinal, J. A. (2012) Body temperatures of Sceloporus anahuacus from a montane zone of northeastern Estado de México, Mexico. Herpetological Bulletin, 121, 27-29.

Ayers, D. Y., Shine, R. (1997) Thermal influences on foraging ability: body size, posture and cooling rate of an ambush predator, the python Morelia spilota. Functional Ecology, 11, 342-347. https://doi.org/10.1046/j.1365-2435.1997.00093.x

Bartholomew, G. A. (1982) Physiological control of body temperature. Pp. 167-211. In: C. Gans, F. H. Pough (Eds.). Biology of the Reptilia. Vol. 12. Academic Press, New York, USA.

Bogert, C. M. (1949) Thermoregulation and eccritic body temperatures in Mexican lizards of the genus Sceloporus. Anales del Instituto de Biología de la Universidad Nacional Autónoma de México, 20, 415-426.

Brattstrom, B. H. (1965) Body temperatures of reptiles. American Midland Naturalist, 73, 376-422. https://dx.doi.org/10.2307/2423461

Brown, R. P., Griffin, S. (2005) Lower selected body temperatures after food deprivation in the lizard Anolis carolinensis. Journal of Thermal Biology, 30, 79-83. https://dx.doi.org/10.1016/j.jtherbio.2004.07.005

Casas-Andreu, G., Gurrola-Hidalgo, M. A. (1993) Comparative ecology of two species of Cnemidophorus in coastal Jalisco, Mexico. Pp. 133-150. In: J. W. Wright, L. J. Vitt (Eds.). Biology of whiptail lizards (genus Cnemidophorus). University of Oklahoma Press, Norman, USA.

Chen, X. J., Xu, X. F., Ji, X. (2003) Influence of body temperature on food assimilation and locomotor performance in white-striped grass lizards, Takydromus wolteri (Lacertidae). Journal of Thermal Biology, 28, 385-391. https://doi.org/10.1016/S0306-4565(03)00022-6

Clusella-Trullas, S., Chown, S. L. (2014) Lizard thermal trait variation at multiple scales: a review. Journal of Comparative Physiology B, 184, 5-21. https://doi.org/10.1007/s00360-013-0776-x

Crowley, S. R. (1985) Thermal sensitivity of spring-running in the lizard Sceloporus undulatus: support for a conservative view of thermal physiology. Oecologia, 66, 219-225. https://doi.org/10.1007/BF00379858

García, E. (1973) Modificaciones al sistema de clasificación climática de Köppen. Segunda Edición. Instituto de Geografía, UNAM, México, Distrito Federal, México, 246 pp.

Gillis, R. (1991) Thermal biology of two populations of red-chinned lizards (Sceloporus undulatus erythrocheilus) living in different habitats in south-central Colorado. Journal of Herpetology, 25, 18-23. https://dx.doi.org/10.2307/1564789

Granados Sánchez, D., López Ríos, G. F., Hernández García, M. A., Sánchez-González, A. (2004) Ecología de la fauna silvestre de la Sierra Nevada y la Sierra del Ajusco. Revista Chapingo, Serie Ciencias Forestales y del Ambiente, 10, 111-117.

Grant, B. W., Dunham, A. E. (1988) Thermally imposed time constraints on the activity of the desert lizard Sceloporus merriami. Ecology, 69, 167-176.

https://dx.doi.org/10.2307/1943171 
Güizado-Rodríguez, M. A., Ballesteros-Barrera, C., Casas-Andreu, G., Barradas-Miranda, V. L., Téllez-Valdés, O., Salgado-Ugarte, I. H. (2012) The impact of global warming on the range distribution of different climatic groups of Aspidoscelis costata costata. Zoological Science, 29, 834-843.

https://dx.doi.org/10.2108/zsj.29.834

Güizado-Rodríguez, M. A., García-Vázquez, U. O., Solano-Zavaleta, I. (2011) Thermoregulation by a population of Sceloporus palaciosi from Sierra del Ajusco, Distrito Federal, Mexico. The Southwestern Naturalist, 56, 120-124. https://dx.doi.org/10.1894/PAS-17.1

Heath, J. E. (1964) Reptilian thermoregulation: evaluation of field studies. Science, 146, 784-785. https://dx.doi.org/10.1126/science.146.3645.784

Herczeg, G., Herrero, A., Saarikivi, J., Gonda, A., Jäntti, M., Merilä, J. (2008) Experimental support for the cost-benefit model of lizard thermoregulation: the effects of predation risk and food supply. Oecologia, 155, 1-10.

https://dx.doi.org/10.1007/s00442-007-0886-9

Hitchcock, M. A., McBrayer, L. D. (2006) Thermoregulation in nocturnal ecthotherms: seasonal and intraspecific variation in the Mediterranean gecko (Hemidactylus turcicus). Journal of Herpetology, 40, 185-195. https://dx.doi.org/10.1670/233-04A.1

Janzen, F. J. (1994) Climate change and temperature-dependent sex determination in reptiles. Proceedings of the National Academy of Science, 91, 7487-7490. https://doi.org/10.1073/pnas.91.16.7487

Juliana, J. R. St., Bowden, R. M., Janzen, F. J. (2004) The impact of behavioral and physiological maternal effects on offspring sex ratio in the common snapping turtle, Chelydra serpentina. Behavioral Ecology Sociobiology, 56, 270-278. https://doi.org/10.1007/s00265-004-0772-y

Kearney, M. (2001) Postural thermoregulatory behavior in the nocturnal lizards Christinus marmoratus and Nephrurus milii (Gekkonidae). Herpetological Review, 32, 11-14.

Lara-Góngora, G. (1983) Two new species of the lizard genus Sceloporus (Reptilia, Sauria, Iguanidae) from the Ajusco and Ocuilán Sierras, Mexico. Bulletin of the Maryland Herpetological Society, 19, 1-14.

Lara-Reséndiz, R. A., García-Vázquez, U. O. (2013) Natural History Notes: Sceloporus anahuacus (Anahuacan Graphic Lizard). Selected body temperature. Herpetological Review, 44, 682683.

Lara-Reséndiz, R. A., Larraín-Barrios, B. C., Díaz de la Vega-Pérez, A. H., Méndez-de la Cruz, F. R. (2014) Calidad térmica a través de un gradiente altitudinal para una comunidad de lagartijas en la Sierra del Ajusco y el Pedregal de San Ángel, México. Revista Mexicana de Biodiversidad, 85, 885-897.

http://dx.doi.org/10.7550/rmb.42249

Lee, J. C. (1980) Comparative thermal ecology of two lizards. Oecologia, 44, 171-176. http://dx.doi.org/10.1007/BF00572675

Lemos-Espinal, J. A., Ballinger, R. E., Sarabia, S. S., Smith, G. R. (1997a) Thermal ecology of the lizard Sceloporus mucronatus mucronatus in Sierra del Ajusco, Mexico. The Southwestern Naturalist, 42, 344-347. 
Lemos-Espinal, J. A., Smith, G. R., Ballinger, R. E. (1997b) Thermal ecology of the lizard, Sceloporus gadoviae, in an arid tropical scrub forest. Journal of Arid Environment, 35, 311319.

https://dx.doi.org/10.1006/jare.1995.0150

Lemos-Espinal, J. A., Smith, G. R., Ballinger, R. E. (1998) Thermal ecology of the crevice-dwelling lizard, Xenosaurus newmanorum. Journal of Herpetology, 32, 141-144. https://dx.doi.org/10.2307/1565498

Llewelyn, J., Shine, R., Webb, J. K. (2005) Thermal regimens and diel activity patterns of four species of small elapid snakes from south-eastern Australia. Australian Journal of Zoology, $53,1-8$. https://doi.org/10.1071/ZO04037

López-Alcaide, S., Nakamura, M., Macip-Ríos, R., Martínez-Meyer, E. (2014) Does behavioural thermoregulation help pregnant Sceloporus adleri lizards in dealing with fast environmental temperature rise? The Herpetological Journal, 24, 41-47.

Lymburner, A. H., Blouin-Demers, G. (2020) Changes in thermal quality of the environment along an elevational gradient affect investment in thermoregulation by Yarrow's spiny lizards. Journal of Zoology, 312, 133-143. https://doi.org/10.1111/jzo.12818

Mathies, T., Andrews, R. M. (1995) Thermal and reproductive biology of high and low elevation populations of the lizard Sceloporus scalaris: implications for the evolution of viviparity. Oecologia, 104, 101-111. https://doi.org/10.1007/BF00365568

Mathies, T., Andrews, R. M. (1997) Influence of pregnancy on the thermal biology of the lizard, Sceloporus jarrovi: why do pregnant females exhibit low body temperatures? Functional Ecology, 11, 498-507. https://dx.doi.org/10.1046/j.1365-2435.1997.00119.x

Mayhew, W. W. (1968) Biology of desert amphibians and reptiles. Pp. 195-356. In: G. W. Brown Jr. (Ed.). Desert Biology: Special Topics on the Physical and Biological Aspects of Arid Regions. Vol. I. Academic Press, New York, USA.

McGinnis, S. M. (1966) Sceloporus occidentalis: preferred body temperature of the western fence lizard. Science, 152, 1090-1091.

Mondal, S., Rai, U. (2001) In vitro effect of temperature on phagocytic and cytotoxic activities of splenic phagocytes of the wall lizard, Hemidactylus flaviviridis. Comparative Biochemistry and Physiology Part A: Molecular and Integrative Physiology, 129, 391-398. https://doi.org/10.1016/S1095-6433(00)00356-1

Mueller, C. F. (1970) Temperature acclimation in two species of Sceloporus. Herpetologica, 26, 8385.

Pérez-Quintero, J. C. (1994) Thermal ecology in a salt-marsh population of Chalcides chalcides. Resúmenes, Herpetología, III Congreso Luso-Español and VII Congreso Español, Badajoz, 19-23 September 1984.

Pianka, E. R. (1973) The structure of lizard communities. Annual Review of Ecology and Systematics, 4, 53-74. https://dx.doi.org/10.1146/annurev.es.04.110173.000413 
Pianka, E. R., Vitt, L. J. (2003) Lizards: windows to the evolution of diversity. University of California Press, Berkeley, California, USA.

Sinervo, B., Adolph, S. C. (1989) Thermal sensitivity of growth rate in hatchling Sceloporus lizards: environmental, behavioral and genetic aspects. Oecologia, 78, 411-419. https://dx.doi.org/10.1007/BF00379118

Sinervo, B. (1990) Evolution of thermal physiology and growth rate between populations of the western fence lizard (Sceloporus occidentalis). Oecologia, 83, 228-237. https://doi.org/10.1007/BF00317757

Smith, G. R., Ballinger, R. E. (1994) Thermal ecology of Sceloporus virgatus from southeastern Arizona, with comparison to Urosaurus ornatus. Journal of Herpetology, 28, 65-69. https://dx.doi.org/10.2307/1564682

Stapley, J. (2006) Individual variation in preferred body temperature covaries with social behaviours and colour in male lizards. Journal of Thermal Biology, 31, 362-369.

https://dx.doi.org/10.1016/j.jtherbio.2006.01.008

Stevenson, R. D., Peterson, C. R., Tsuji, J. S. (1985) The thermal dependence of locomotion, tongue flicking, digestion, and oxygen consumption in the wandering garter snake. Physiological Zoology, 58, 46-57.

https://dx.doi.org/10.1086/physzool.58.1.30161219

Tattersall, G. J., Milsom, W. K., Abe, A. S., Brito, S. P., Andrade, D. V. (2004) The thermogenesis of digestion in rattlesnakes. Journal of Experimental Biology, 207, 579-585. https://dx.doi.org/10.1242/jeb.00790

Van Damme, R., Bauwens, D., Verheyen, R. F. (1986) Selected body temperatures in the lizard Lacerta vivipara: variation within and between populations. Journal of Thermal Biology, 11, 219-222. https://dx.doi.org/10.1016/0306-4565(86)90006-9

Vial, J. L. (1984) Comparative field responses to diel and annual thermal regimes among Sceloporine lizards, with specific reference to Sceloporus malachiticus. Revista de Biología Tropical, 32, 1-9.

Wilhoft, D. C., Anderson, J. D. (1960) Effect of acclimation on the preferred body temperature of the lizard, Sceloporus occidentalis. Science, 131, 610-611.

https://dx.doi.org/10.1126/science.131.3400.610

Zamora-Camacho, F. J., Reguera, S., Moreno-Rueda, G. (2016) Thermoregulation in the lizard Psammodromus algirus along a 2200-m elevational gradient in Sierra Nevada (Spain). International Journal of Biometeorology, 60, 687-697.

https://doi.org/10.1007/s00484-015-1063-1 